\title{
Variation in abundance and habitat relationship of three understory insectivorous birds in a disturbed landscape of Neotropical dry forest of Colombia
}

\author{
Camilo Loaiza $^{{ }^{*}} \mathbb{0}$, Olga L. Montenegro' ${ }^{1}$ David King ${ }^{2}$, Manuel Spínola ${ }^{3}$, Lilibeth Arinda Palacio
} and Agustín Rudas ${ }^{1}$

\begin{abstract}
Background: Evaluating relationships between avian populations and their habitat is important for understanding the biology of these species and for management decisions that improve the effectiveness of restoration practices. We investigated how habitat variation along a disturbance gradient affected the abundance of three insectivorous bird species, White-bellied Antbird (Myrmeciza longipes), Barred Antshrike (Thamnophilus doliatus), and Pale-breasted Spinetail (Synallaxis albescens) in a Neotropical dry forest remnant in central Colombia.

Methods: The study area, which is located in Magdalena Valley, is under ecological restoration after the construction of the "El Quimbo" hydroelectric dam, with a gradient of habitat conditions, from relatively advanced secondary growth to recently disturbed areas. We conducted bird surveys and quantified the habitat conditions from June 2018 to June 2019. We compared the relative abundance of the birds among the three zones with increasing disturbance and modeled the relationship between the bird abundance with the micro- and landscape-habitat conditions, with Poisson generalized linear model regression.

Results: The relative abundance of the three bird species varied according to the habitat features and disturbance level. The abundance of White-bellied Antbirds was higher in forests and thickets than shrubland fragments; Barred Antshrike was more abundant in shrubland and thickets than in forest fragments, and Pale-breasted Spinetail had the highest abundance in shrubland and the lowest in forest fragments. The abundance of both White-bellied Antbird and Pale-breasted Spinetail did not differ among zones with different levels of disturbance, while the abundance of Barred Antshrike decreased in zones with more disturbance.

Conclusions: There were significant differences in the habitat relationships of the three understory insectivorous species along the disturbance gradient, although these species were within the same trophic group. These bird species preferred different stages of habitat succession and responded to different habitat and landscape features. Increasing forest fragment areas and decreasing the amount of edge would be useful restoration priorities for these and other similar avian species in this study area.
\end{abstract}

Keywords: Bird population ecology, Generalized linear models, Wildlife habitat restoration

*Correspondence: cloaiza_81@yahoo.com

${ }^{1}$ Instituto de Ciencias Naturales, Universidad Nacional de Colombia, Bogotá, Colombia

Full list of author information is available at the end of the article

\section{Background}

Habitat degradation resulting from the expansion of agriculture and conversion of land for urban settlement has affected wildlife species (Kilpatrick et al. 2017). As 
a consequence of human population growth, development projects, such as hydroelectric dams, have resulted in the loss of natural habitats and wildlife populations (Benedict and McMahon 2002). Ecological stressors to terrestrial wildlife from dam construction and operation may include habitat fragmentation and loss (Cosson et al. 1999; Andriolo et al. 2013; Fearnside 2014). In India, researchers reported terrestrial vertebrate abundance and species richness declines following dam construction (Pandit and Grumbine 2012). In addition, in the Amazon region, scientists have identified birds as a vulnerable group because of their habitat loss due to hydroelectric projects (Vale et al. 2008).

Currently, neotropical dry forests are considered one of the most threatened ecosystems worldwide. In Colombia, tropical dry forests have been highly reduced, and they are poorly represented in the national system of protected areas (Pizano and García 2014). Therefore, the creation of Colombian tropical dry forest conservation areas represents an urgent priority (Barrance et al. 2009; Losada-Prado and Molina-Martinez 2011; Pizano and García 2014). The disturbance of Colombian dry forests is a consequence of many years of human settlement and cattle and agricultural activity because of their favorable climactic conditions and fertile soils, resulting in high rates of fragmentation and degradation. Recently, other factors, such as mining, urban development, and tourism, have been pressuring those remnants (Pizano and García 2014).

In the Upper Magdalena Valley, central Colombia, the environmental ministry was obligated to fulfill a compensation action owing to the ecological damages caused by the construction of the "El Quimbo" hydroelectric project, acquiring an area of 11,079 ha of tropical dry forest that have been under restoration since 2014. The area encompasses a disturbance gradient from relatively pristine areas to sites impacted by human settlement, and associated cattle and agricultural activities have been gradually abandoned since the 1980s (Natura 2015). Cattle live without fences and frequently cross natural vegetation fragments, altering the structure of the understory, and therefore are considered the main anthropic threat to restoration (Tamayo 2020). Sowing native plant species with seeds recovered from around the area is one of several restoration strategies. Managers expect that by the year 2038, the area will be a mature tropical dry forest ecosystem, and will then be transferred to the Colombian Natural National Parks Agency as a new national protected area (Natura 2017) (Fig. 1).

Understory insectivorous birds are vulnerable to habitat degradation, and occupy the low vertical strata between 0 and $3 \mathrm{~m}$ above the ground (Walther 2002). Although these birds vary in their ecological characteristics, in general, they are susceptible to fragmentation, mainly owing to their diet specialization, foraging near the ground, and sensitivity to edge effects and other human disturbances (Rosenberg 1990; Stouffer and Bierregaard 1995; Canaday 1997; Marra and Remsen 1997; Stratford and Stouffer 1999). Furthermore, many tropical understory insectivorous birds are sedentary, with high habitat specificity and stable territory defenders, making them vulnerable and reactive to habitat complexity (Sigel et al. 2006; Castaño-Villa et al. 2014, 2019).

We investigated how habitat variation along a disturbance gradient affected the abundance of three insectivorous bird species: White-bellied Antbird (Myrmeciza longipes), Barred Antshrike (Thamnophilus doliatus), and Pale-breasted Spinetail (Synallaxis albescens) in a tropical dry forest remnant of the Upper Magdalena Valley in Colombia. We wanted to address the research questions: (1) as a consequence of agricultural, cattle grazing, and dam construction and operation, how do the differences in habitat variables between three zones of the environmental compensation area of the "El Quimbo" project translate into differences in the abundance of the three understory insectivorous birds species? and (2) which habitat variables should managers focus on to restore this area for these bird species?

\section{Methods}

\section{Study area}

We developed this study in a remnant of a neotropical dry forest located around the "El Quimbo" hydroelectric dam $\left(2^{\circ} 15^{\prime} 56.032^{\prime \prime} \mathrm{N} ; 75^{\circ} 40^{\prime} 40.8576^{\prime \prime} \mathrm{W}\right)$, which represents a gradient of conditions, from relatively advanced secondary growth to recently disturbed areas, over a total of 11,079 ha. This land was designated for restoration, because of a compensation action following the Colombian environmental legislation related to dam building. Restoration activities are carried out by Fundación Natura, a non-governmental organization focused on biodiversity conservation (Morales 2015; Natura 2017).

The environmental compensation area of the "El Quimbo" hydroelectric project is located in four different municipalities of central Colombia: Paicol, Agrado, Gigante, and Garzón (Fig. 1). The altitude ranges from 720 to $1500 \mathrm{~m}$, and the temperature varies from 20 to $26^{\circ} \mathrm{C}$. Two rainy seasons occur yearly: the first one between October and November, and the second between March and April. The dry season occurs between June and August, and rainfall varies from $900 \mathrm{~mm}$ in the southern sector to $1900 \mathrm{~mm}$ in the western sector of the area. Climatic zones are clearly identified; the annual rainfall increases with altitude. The wettest area is located in the west and the driest is located in the south (Pinzón 2014; Natura 2017). 


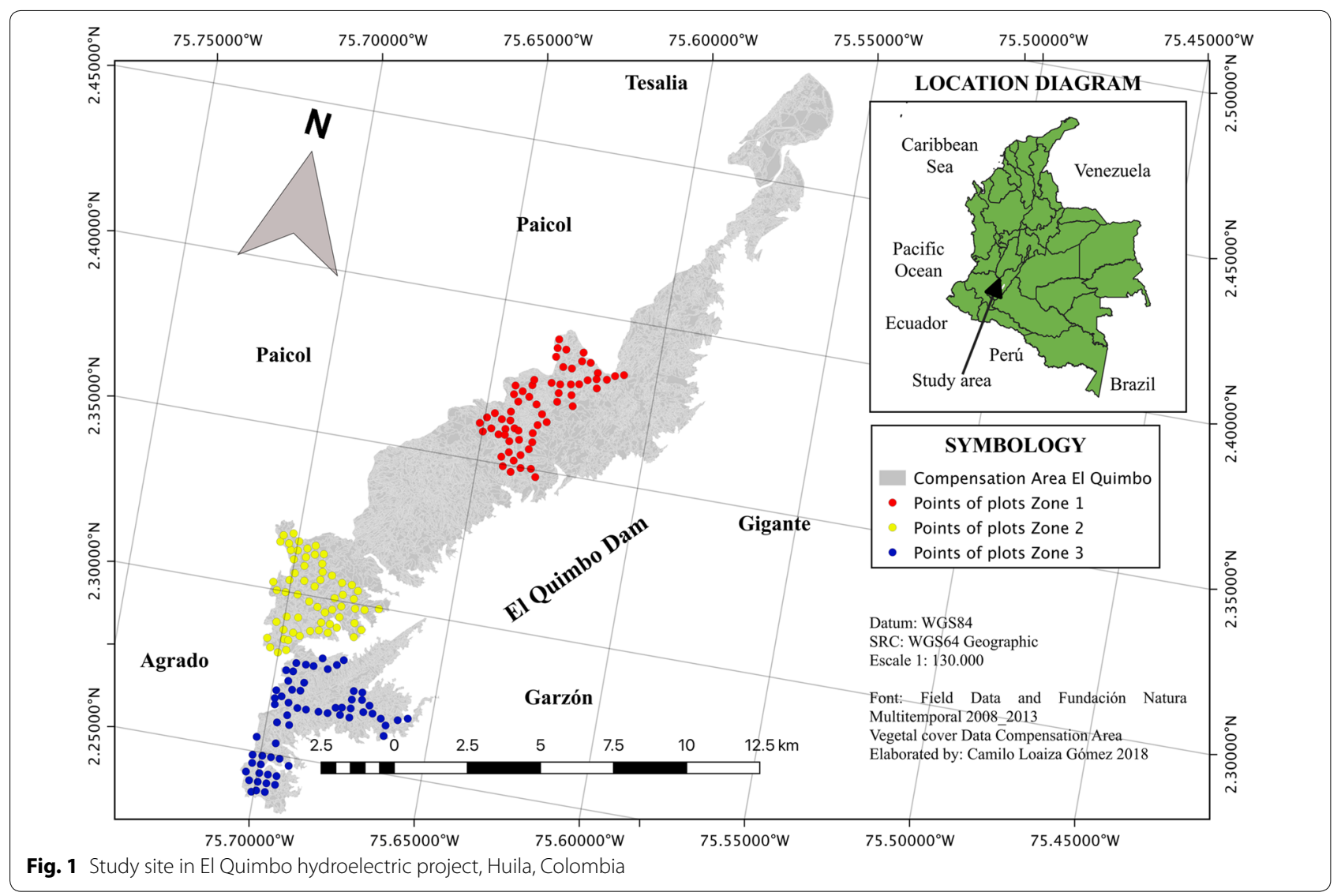

\section{Species selection}

We selected three species of understory insectivorous birds as focal species for this study: White-bellied Antbird (Myrmeciza longipes) (Swainson 1825), Barred Antshrike (Thamnophilus doliatus) (Linnaeus 1764), and Pale-breasted Spinetail (Synallaxis albescens) (Temminck 1823). These species were resident and abundant at our sites and provided sufficient numbers for assessing the effects of anthropogenic disturbance.

In Colombia, White-bellied Antbirds are distributed from sea level up to $700 \mathrm{~m}$, although they have been known to reach up to 1750 m near the Magdalena River (Hilty and Brown 2001). The species prefers secondary deciduous and semi-deciduous forests, gallery forests, and humid rainforests, and generally forages near the ground (Hilty and Brown 2001; DiGiovanni and Pollock 2018); it forages for arthropods in the leaf litter, the lower layers of the forest, and the branches. The Barred Antshrike is associated with secondary Colombian forests, gallery forests, and forest edges, from 1500 to $1800 \mathrm{~m}$ (Hilty and Brown 2001; Sekercioglu 2009; Koloff and Mennill 2011a). This species uses the middle strata, taking advantage of the regeneration of successions (Gillies and St Clair 2010; Gaitán García 2013) and searching for insects on leaves, stems, epiphytes, vines, and trunks (Poulin et al. 1994; Koloff and Mennill 2011b; Zimmer et al. 2018). The Pale-breasted Spinetail prefers disturbed habitats (Remsen 2018); it frequently forages in open areas and feeds in bushes, grasslands, regenerating pastures, meadows, scattered trees, savannas, living fences on the edges of marshes, secondary growths, and agricultural areas, as well as on roadsides (Marone 1992; Remsen 2018).

\section{Sampling methods}

We divided the study area into three different zones according to the gradient of disturbance (Natura 2015). We established 186 survey points, 62 for each zone, along gradients of disturbance and elevation range, with a minimum distance of approximately $300 \mathrm{~m}$ to minimize recounting of the same birds (Mansor and Ramli 2017). We selected those points on a map, considering access logistics and avoiding grassy areas without shrubs and/ or trees. We visited each point three times, completed in seven field trips over a period of 13 months (June 2018 to June 2019). Each visit to a point was made during one of the three climatic seasons: rainy, transition, or dry. The order of the surveys was planned for access logistics. 
For each point count, we surveyed birds for $10 \mathrm{~min}$ with binoculars, followed by $10 \mathrm{~min}$ of monitoring using playback, and finally $2-3$ min of passive listening. We downloaded the broadcast songs from xeno-canto.org and played them with Bluetooth speakers at a maximum volume of $100 \mathrm{~dB}$ to avoid the attraction of individuals from other points (Chandler and King 2011). We rotated the order in which audio recordings were played among visits. During each survey, we recorded the species, the number of individuals, their gender (in the Barred Antshrike because of its sexual dimorphism), and the period when individuals were detected during the observation (before the playback, during the playback or after the playback). We used total detections at each point for statistical analysis and visited points between two periods during the day: 6:00-11:30 and 15:00-18:00 h. Each point survey was conducted by three people: a researcher, auxiliary researcher, and guide.

Habitat features within a $50 \times 50 \mathrm{~m}$ radius of each point were assessed. Each plot was divided into four quadrants (q1-q4) and numbered using the magnetic north by means of a compass. We measured the habitat variables inside those quadrants randomly, and calculated a mean value for each variable. We excluded quadrants without vegetation cover in the calculations. Habitat quantification was completed after the bird surveys.

\section{Habitat variables}

We assessed habitat variables based on available literature on the life history requirements related to the resting, reproduction, and feeding of the three bird species. We measured the leaf litter depth with a metallic ruler as an average of one random measure for each quadrant (DiGiovanni and Pollock 2018; H.S. Pollock unpublished data). We surveyed the shrubland fragments area and forest fragments area using ArcGIS 10.0 software (2010) based on a thematic map of the study area, by means of a "multispectral classification" (Loaiza 2020), and using Landsat 8 OLI satellite imaging from January 2019 (downloaded from https://earthxplorer.usgs.gov). We created a buffer of 7.06 ha (a circle with a radius of $150 \mathrm{~m}$ ) around each point count and intersected it with the thematic map. We calculated the area of each vegetation type inside the buffer. We summed all values of shrubland types to obtain one value for each point. We performed the same procedure for forest types (Hilty and Brown 2001; Sekercioglu 2009; Gillies and St Clair 2010; Gaitán García 2013; DiGiovanni and Pollock 2018). We calculated the fragment edge index from the "multispectral classification" of the Landsat image. We recategorized the map into four different classes: natural, transformed, river, and water bodies and intersected the results with the buffers around the point counts. We calculated an index as the difference between the sum of edge (natural vs. transformed) longitude in the buffer and the value of the circle buffer perimeter $(942.273 \mathrm{~m})$. The literature suggests that Barred Antshrike and Palebreasted Spinetail forage in forests and shrubland edges (Sekercioglu 2009; Remsen 2018). We determined the vegetation cover type using the methodology proposed by Edwards (1983), a structural categorization of vegetation designed for practical use, based on vegetation characteristics. We defined one vegetation type in each plot using an adapted dichotomic key (see the key in Additional file 1). The characters were the height of the dominant plant individuals, percentage of cover (measured using a densitometer), and growth form. We found 13 vegetation types across the area; however, for modeling, we combined them into three broad categories: shrubland, forest, and thicket. Thicket was considered an intermedia between forest and shrubland (Hilty and Brown 2001; Marone 1992; Sekercioglu 2009; Koloff and Mennill 2011a; DiGiovanni and Pollock 2018; Remsen 2018).

We recorded the elevation at each point using a GPS (GPS Garmin Map 64; Garmin, Bogotá, Colombia). We registered the slope at each point using the Clinometer and Bubble Level (Plaincode, Stephanskirchen, Germany). We recorded the temperature and relative humidity at each point during each visit using a ThermoHygrometer with Min/Max Function (Tracebale products, Webster, TX, USA) (Additional file 2).

\section{Data analysis}

We performed a multivariate analysis of variance (MANOVA) to compare the environmental variables among the three zones. We excluded the variable "temperature" because it was highly correlated with "humidity" $(r=0.82)$. The elevation $(\mathrm{m})$, average relative humidity (\%), slope $\left(^{\circ}\right)$, shrubland fragment area (ha), forest fragment area (ha), and fragment edge index $(\mathrm{m})$ were the dependent variables for MANOVA. After detecting the global significance, we identified significant dependent variables with an analysis of variance (ANOVA), followed by a Tukey test for comparisons among the three zones in R (R Core Team 2018). We fitted a principal component analysis (PCA) with selected habitat variables to complement the MANOVA. In addition, we fitted two linear models to examine their relationship with the gradient across the study zone: the first had the temperature $\left({ }^{\circ} \mathrm{C}\right)$ as the response variable, and time, elevation $(\mathrm{m})$, and vegetation cover type as predictors; and the second had relative humidity (\%) as the response variable and elevation $(\mathrm{m})$ and vegetation cover type as predictors (Additional file 2). Generalized linear models (GLMs) are useful approaches to assess which variables influence bird abundance, so we fitted a GLM for the counts (Poisson 
distribution) of the three species, taking the maximum number of individuals at each point as the abundance index (Toms et al. 2006). We grouped the abundance survey detection periods because we considered suitable in abundance relationships with habitat. Additionally, we found most of the detections during playback, so we considered the other two periods as complementary samples. We included the leaf litter depth, forest fragment area, shrubland fragment area, fragment edge index, vegetation cover type, elevation, slope, zone, and relative humidity as predictors (Wickham 2016; Wilke and Cowplot 2019). We selected models using Akaike's information criterion for small sample sizes (AICc) (Burnham and Anderson 2002). We considered three criteria to assess the effects of habitat variables on abundance. First, we checked whether the variable was present in the best-supported model. Second, we considered whether the variable was present in the other supported models. Third, we checked in the average model if the variable had a coefficient that included zero in their confidence interval (Tables 1,2). We tested the overdispersion of the dependent variable by comparing the mean and variance with the function "dispersionless" to confirm whether the Poisson distribution was the best option to fit our data (Kleiber and Zeileis 2008; Grosjean et al. 2018). We considered the best-supported models with $\Delta \mathrm{AIC} \leq 2$, since the main objective of this research was to understand the abundance of the three bird species as a function of habitat variables (Chandler and King 2011). We used model averaging of the best-supported models for the abundance per zone calculations (Tables 1, 2; R code in Additional file 3).

\section{Results}

The supported models $(\triangle \mathrm{AICc} \leq 2)$ included the vegetation structure, quantity of biotic resources, and abiotic characteristics (such as elevation, relative humidity, and slope) as good predictors of the three species abundance (Table 1). Thus, the best models detected the most important variables as abundance predictors for these species. The shrubland fragment area and forest fragment area were the best predictors for White-bellied Antbird abundance, while vegetation cover type was the best predictor for the Pale-breasted Spinetail abundance. Moreover, the Barred Antshrike best model included the elevation, vegetation cover type, and zone as abundance predictors. Further, supported models included additional variables, which we considered to predict species abundance (Tables 1,2). All the variables included in the average models had a high level of support because the

Table 1 Generalized linear model (Poisson distribution) selection results of White-bellied Antbird, Barred Antshrike, and Pale-breasted Spinetail at the study area, El Quimbo hydroelectric project, Huila, Colombia, 2018-2019

\begin{tabular}{|c|c|c|c|c|c|}
\hline Species & AICc & Delta AIC & $K$ & Weight & Poisson GLM models \\
\hline \multirow[t]{7}{*}{ White-bellied Antbird } & 430.3 & 0 & 3 & 0.1413 & Abund $=$ shrubarea + forarea \\
\hline & 430.3 & 0 & 4 & 0.1405 & Abund $=$ elev + shrubarea + forarea \\
\hline & 431.5 & 1.2 & 6 & 0.0503 & Abund $=$ elev + shrubarea + forarea + zone \\
\hline & 432 & 1.7 & 5 & 0.0602 & Abund $=$ shrubarea + forarea + typecover \\
\hline & 432.3 & 1.9 & 4 & 0.0537 & Abund $=$ slope + shrubarea + forarea \\
\hline & 432.4 & 2 & 5 & 0.0508 & Abund $=$ elev + leaflitter + shrubarea + forarea \\
\hline & 432.4 & 2 & 5 & 0.0508 & Abund $=$ elev + slope + shrubarea + forarea \\
\hline \multirow[t]{4}{*}{ Barred Antshrike } & 506.2 & 0 & 6 & 0.1346 & Abund $=$ elev + typecover + zone \\
\hline & 507.5 & 1.3 & 7 & 0.0689 & Abund $=$ elev + slope + typecover + zone \\
\hline & 508 & 1.9 & 7 & 0.0527 & Abund $=$ elev + shrubarea + typeocover + zone \\
\hline & 508.2 & 2 & 7 & 0.0459 & Abund $=$ elev + edge + typecover + zone \\
\hline \multirow[t]{8}{*}{ Pale-breasted Spinetail } & 410.3 & 0 & 3 & 0.1522 & Abund $=$ typecover \\
\hline & 411.7 & 1.4 & 5 & 0.0766 & Abund $=$ typecover + zone \\
\hline & 411.7 & 1.4 & 5 & 0.0762 & Abund $=$ elev + slope + typecover \\
\hline & 411.7 & 1.4 & 4 & 0.074 & Abund $=$ slope + typecover \\
\hline & 411.8 & 1.5 & 5 & 0.0717 & Abund $=$ elev + edge + typecover \\
\hline & 412.1 & 1.7 & 5 & 0.0634 & Abund $=$ elev + humaveg + typecover \\
\hline & 412.1 & 1.8 & 4 & 0.614 & Abund $=$ humaveg + typecover \\
\hline & 412.2 & 1.9 & 4 & 0.599 & Abund = edge + typecover \\
\hline
\end{tabular}

Variables are referenced as follows: Abund, abundance (number of individuals per point); shrubarea, area of shrubland in the buffer around the plot (ha); forarea, area of forest in the buffer around the plot (ha); elev, elevation at the plot (m); typecover, vegetation cover type following Edwards (1983); slope, slope at the plot (\%); leaflitter, average leaf litter depth at the plot measured at each quadrant (cm); edge, edge index in the buffer around the plot (m); humaveg, average relative humidity; zone, zone (1, 2, or 3). 
Table 2 Averaging models and 95\% confidence intervals for generalized linear model (Poisson distribution) of Whitebellied Antbird, Barred Antshrike and Pale-breasted Spinetail at the study area, El Quimbo hydroelectric project, Huila, Colombia, 2018-2019

\begin{tabular}{|c|c|c|c|c|c|}
\hline Species & Variable & $\begin{array}{l}\text { Coefficient } \\
\text { in the model }\end{array}$ & Lower & Upper & $\begin{array}{l}\text { Variables } \\
\text { level } \\
\text { of support }\end{array}$ \\
\hline \multirow[t]{10}{*}{ White-bellied Antbird } & Intercept & 0.8763 & 0.1591 & 4.8273 & High \\
\hline & Shrubland area & 1.1329 & 1.0339 & 1.2413 & High \\
\hline & Forest area & 1.1792 & 1.0797 & 1.2878 & High \\
\hline & Elevation & 0.9992 & 0.9968 & 1.0005 & High \\
\hline & Typecover Shrubland & 0.9676 & 0.4632 & 1.1528 & High \\
\hline & Typecover Thicket & 1.001 & 0.7005 & 1.4788 & High \\
\hline & Slope & 1.0003 & 0.9917 & 1.0116 & High \\
\hline & Leaf litter depth & 0.9985 & 0.8767 & 1.1042 & High \\
\hline & Zone 2 & 0.9729 & 0.495362 & 1.3414 & High \\
\hline & Zone 3 & 0.9272 & 0.2943 & 1.1026 & High \\
\hline \multirow[t]{9}{*}{ Barred Antshrike } & Intercept & 15.5486 & 2.596 & 93.092 & High \\
\hline & Elevation & 0.9977 & 0.9958 & 0.9995 & High \\
\hline & Typecover Shrubland & 1.2524 & 0.9029 & 1.7372 & High \\
\hline & Typecover Thicket & 1.4307 & 1.0515 & 1.9446 & High \\
\hline & Slope & 0.9991 & 0.9876 & 1.0046 & High \\
\hline & Shrubland area & 1.0029 & 0.9553 & 1.0829 & High \\
\hline & Edge & 0.999 & 0.9997 & 1.0001 & High \\
\hline & Zone 2 & 0.4225 & 0.2705 & 0.66 & High \\
\hline & Zone 3 & 0.2624 & 0.1562 & 0.4408 & High \\
\hline \multirow[t]{9}{*}{ Pale-breasted Spinetail } & Intercept & 0.3233 & 0.1029 & 1.01578 & High \\
\hline & Typecover Shrubland & 3.0214 & 1.9618 & 4.6531 & High \\
\hline & Typecover Thicket & 1.9212 & 1.2184 & 3.0296 & High \\
\hline & Elevation & 1.0003 & 0.9997 & 1.0022 & High \\
\hline & Slope & 0.9991 & 0.9864 & 1.0065 & High \\
\hline & Edge & 1 & 0.9998 & 1.0002 & High \\
\hline & Relative humidity & 1.000326 & 0.9845 & 1.019 & High \\
\hline & Zone 2 & 1.0082 & 0.7256 & 1.5801 & High \\
\hline & Zone 3 & 0.9693 & 0.5132 & 1.163 & High \\
\hline
\end{tabular}

Variables are referenced as follows: Shrubland area, area of shrubland in the buffer around the plot (ha); Forest area, area of forest in the buffer around the plot (ha); Elevation, elevation at the plot $(\mathrm{m})$; Typecover, vegetation cover type following Edwards (1983); Slope, slope at the plot (\%); Leaf litter depth, average leaf litter depth at the plot measured at each quadrant $(\mathrm{cm})$; Edge, edge index in the buffer around the plot $(\mathrm{m})$; Relative humidity, average relative humidity; Zone, zone $(1,2$, or 3).

confidence intervals of their coefficients did not include zero (Table 2).

The relative humidity, slope, elevation, fragment edge index, area of shrubland fragments, and area of forest fragments differed among disturbance zones $\left(F_{12,358}=25.49, P<0.01\right)$. The differences were as follows: Zone 1 and Zone 2 were wetter than Zone 3; Zone 1 was higher than Zone 2 and much higher than Zone 3; Zone 3 was steeper than Zone 2 and Zone 1; Zone 1 had a greater area of shrubland fragments than Zone 2 and much greater area than Zone 3; Zones 1 and 2 had greater areas of forest fragments than Zone 3; and Zone 2 had a greater fragment edge length than Zone 1 (Table 3 ). Two major components in the PCA explained $76 \%$ of the total variation (Table 4). The first component represented the climatic conditions with lower elevations of hotter and drier sites to higher elevations of cooler and moister sites. The second component represented gradients of disturbance and elevation, with shrub dominated sites at lower elevations to more extensive forest sites at higher elevations (Table 4).

The White-bellied Antbird abundance was positively associated with the area of shrubland and forest fragments, two variables present in all supported models (Table 1). The vegetation cover type was present in only one of the supported models. Forests $(0.71 \pm 0.12)$ and thickets $(0.72 \pm 0.11)$ had higher abundance coefficients ( \pm standard error) than did shrubland fragments 
Table 3 ANOVA and Tukey's test of environmental and biotic variables among three zones of the study area, El Quimbo hydroelectric project, Huila, Colombia, 20182019

\begin{tabular}{|c|c|c|c|c|c|}
\hline & Zone 1 & Zone 2 & Zone 3 & ANOVA & Tukey's test \\
\hline \multicolumn{6}{|c|}{ Relative humidity (\%) } \\
\hline Mean & 70.75 & 69.1 & 59.48 & \multirow{2}{*}{$\begin{array}{l}F_{2,183}=20.93 \\
P<0.01\end{array}$} & \multirow[t]{2}{*}{$1-3 / 2-3$} \\
\hline SE & 1.19 & 1.49 & 1.29 & & \\
\hline \multicolumn{6}{|c|}{ Elevation (m) } \\
\hline Mean & 1000.08 & 819.06 & 778.23 & \multirow{2}{*}{$\begin{array}{l}F_{2,183}=142.23 \\
P<0.01\end{array}$} & \multirow{2}{*}{$1-3 / 2-3 / 1-2$} \\
\hline SE & 12.78 & 10.81 & 3.71 & & \\
\hline \multicolumn{6}{|c|}{ Slope (\%) } \\
\hline Mean & 27.59 & 25.16 & 36.01 & \multirow{2}{*}{$F_{2,183}=7.83, P<0.01$} & \multirow[t]{2}{*}{$1-3 / 3-2$} \\
\hline SE & 1.97 & 1.75 & 2.51 & & \\
\hline \multicolumn{6}{|c|}{ Shrubland area (ha) } \\
\hline Mean & 3.89 & 2.73 & 1.36 & \multirow{2}{*}{$\begin{array}{c}F_{2,183}=23.72 \\
P<0.01\end{array}$} & \multirow[t]{2}{*}{$1-3 / 2-3 / 1-2$} \\
\hline SE & 0.28 & 0.29 & 0.21 & & \\
\hline \multicolumn{6}{|c|}{ Forest area (ha) } \\
\hline Mean & 2.26 & 1.88 & 0.44 & \multirow{2}{*}{$\begin{array}{l}F_{2,183}=15.63 \\
P<0.01\end{array}$} & \multirow[t]{2}{*}{$1-3 / 3-2$} \\
\hline SE & 0.30 & 0.27 & 0.13 & & \\
\hline \multicolumn{6}{|c|}{ Edge (m) } \\
\hline Mean & 482.93 & 807.34 & 574.45 & \multirow{2}{*}{$F_{2,183}=3.92, P<0.05$} & \multirow[t]{2}{*}{$1-2$} \\
\hline SE & 73.1 & 108.51 & 65.55 & & \\
\hline
\end{tabular}

Tukey's test numbers refer to significant differences between zones. SE standard error

Table 4 Principal components analyses of 186 points based on elevation and climactic and habitat characteristics at the study area, El Quimbo hydroelectric project, Huila, Colombia, 2018-2019

\begin{tabular}{lcc}
\hline & PC1 & \multicolumn{1}{c}{ PC2 } \\
\hline Proportion of variance & 0.4843 & 0.2805 \\
Elevation & 0.4069 & -0.4296 \\
Humidity & 0.5784 & 0.1551 \\
Temperature & -0.5622 & -0.0788 \\
Shrub area & 0.2044 & -0.7289 \\
Forest area & 0.3767 & 0.5402
\end{tabular}

Elevation, Elevation at the plot ( $\mathrm{m}$ ); Humidity, average relative humidity (\%); Temperature, in Celsius degrees; Shrub area, area of shrubland in the buffer around the plot (ha); Forarea, area of forest in the buffer around the plot (ha).

$(0.51 \pm 0.09)$ (Fig. 2). Because of the inclination of the curve, the leaf litter depth had a weak negative effect, and the slope had a weak positive effect on the abundance (Table 1, Additional file 4).

The Barred Antshrike abundance was positively associated with the shrubland area (Table 1). Antshrikes were more abundant in thickets $(1.58 \pm 0.18)$ and shrublands $(1.39 \pm 0.18)$ than in forest fragments $(1.11 \pm 0.12)$. The vegetation cover type was present in all supported models. The edge index had a negative effect although it was included only in one of the supported models (Table 1, Fig. 3). The slope and elevation had strong negative effects on the abundance (Table 1, Additional file 4).

The Pale-breasted Spinetail abundance was more positively associated with shrublands $(1.28 \pm 0.15)$ than with thickets $(0.81 \pm 0.11)$, and more abundant in thickets than forest fragments $(0.43 \pm 0.07)$. The vegetation cover type was present in the best candidate model and in all the other supported models (Table 1, Fig. 4). The slope showed a weak negative effect and the elevation showed a positive effect on the spinetail abundance (Table 1, Additional file 4).

Because the standard errors overlapped, the Whitebellied Antbird abundance (mean birds/point \pm standard error) was similar among zones $1(0.84 \pm 0.116), 2$ $(0.82 \pm 0.08)$, and $3(0.78 \pm 0.127)$. Likewise, the Palebreasted Spinetail abundance was equal among zones: Zone $1(0.42 \pm 0.07)$, Zone $2(0.43 \pm 0.08)$, and Zone 3 $(0.41 \pm 0.08)$. Finally, the Barred Antshrike abundance displayed the following differences among zones; it was the highest in Zone 1 (2.089 \pm 0.327$)$, followed by Zone 2 $(0.88 \pm 0.142)$, and Zone $3(0.54 \pm 0.111)$ (Table 2, Fig. 5).

\section{Discussion}

The study area encompassed a broad gradient of conditions, from relatively advanced secondary growth to recently disturbed areas, which enabled us to examine the responses of the birds to disturbance (Natura 2015). Although we divided the study area into three zones based on the level of disturbance, we found that the zones were an irrelevant variable for modeling the abundance of Pale-breasted Spinetail and White-bellied Antbird; in both cases, the zones were not included in the best model, and were thus present in only one of the supported models. Therefore, we found similarities among the abundance estimations in the three zones. Thus, we will focus on associations between the habitat variables and abundance across the entire gradient, without including the relationship with the zones, for the antbird and the spinetail.

Agreeing with DiGiovanni and Pollock (2018), we conclude that White-bellied Antbirds tolerate disturbance, as indicated by the similar abundance estimations across the disturbance gradient. However, the antbird abundance was positively related to the forest area, suggesting that the persistence of this species in fragmented landscapes depends on the presence of remnant forest patches (Hilty and Brown 2001). Furthermore, the higher vertical complexity of habitat structure provided by the understory of forests and thickets, relative to shrublands, provides more food and cover for the movement of these birds (Gillies and St Clair 2010; Castaño-Villa et al. 

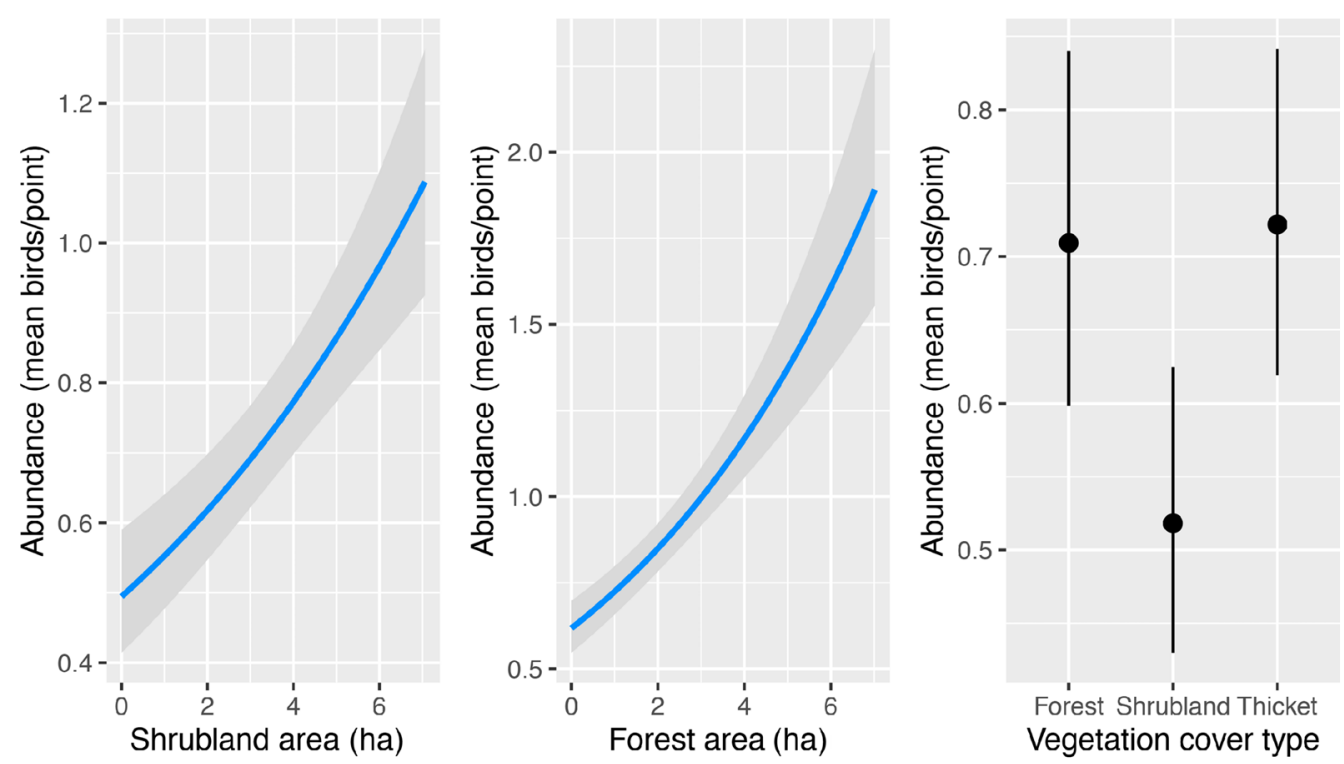

Fig. 2 Relative abundance of White-bellied Antbird in relation with shrubland area, forest area, and vegetation cover type at the study area, El Quimbo hydroelectric project, Huila, Colombia. Error band is $\pm 1 \mathrm{SE}$. The shrubland area was significantly different among all zones, while the forest area showed significant differences between both zones 2 and 3 and 1 and 3
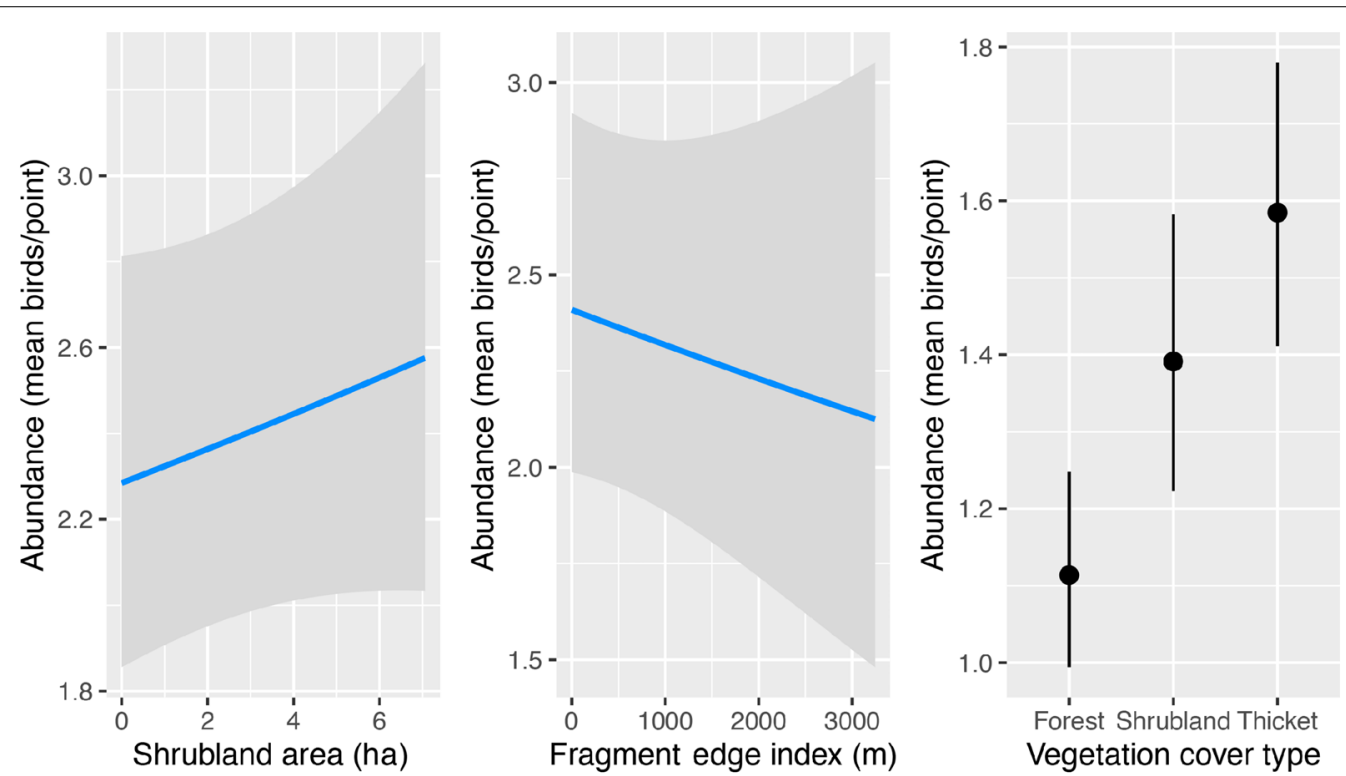

Fig. 3 Relative abundance of Barred Antshrike in relation with the shrubland area, fragment edge index, and vegetation cover type at the study area, El Quimbo hydroelectric project, Huila, Colombia. Error band is \pm 1 SE. The shrubland area was significantly different among all zones, while the fragment edge index showed significant differences between zones 1 and 2

2014). Other researchers have suggested that these birds are associated with specific microclimate conditions in tropical dry forests, where temperatures are extreme (Block and Brennan 1993; Franklin et al. 2000; CastañoVilla et al. 2014; Pollock et al. 2015). Our results indicate that the temperature was the lowest in forest fragments $\left(26.6 \pm 0.27{ }^{\circ} \mathrm{C}\right)$, compared to that in thicket fragments $\left(27.7 \pm 0.29^{\circ} \mathrm{C}\right)$ and shrubland fragments $\left(28.2 \pm 0.31{ }^{\circ} \mathrm{C}\right)$ (Additional file 2). Similarly, relative humidity was higher in forest fragments $(69.7 \% \pm 1.15 \%)$ than in shrubland 

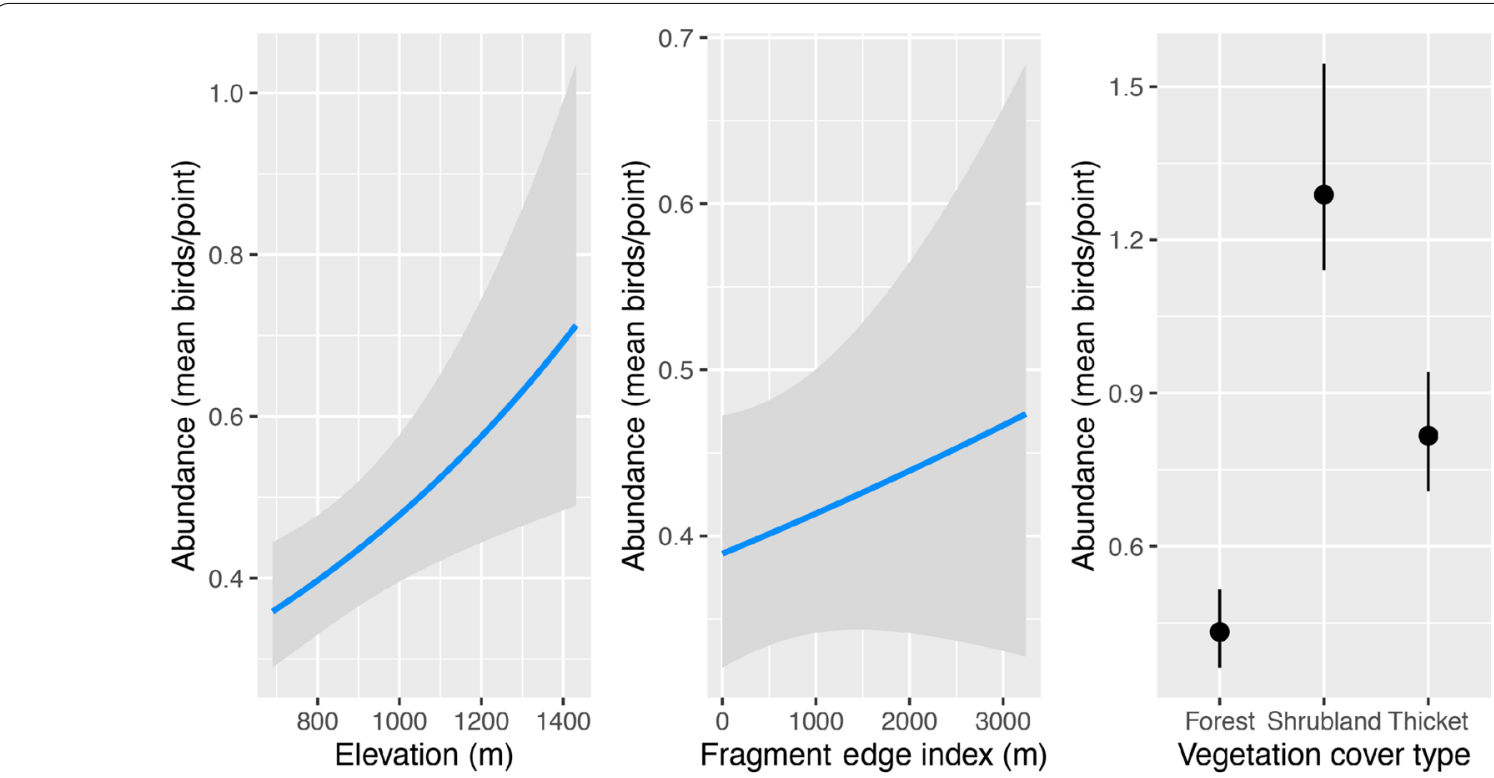

Fig. 4 Relative abundance of Pale-breasted Spinetail in relation with elevation, fragment edge index and vegetation cover type at the study area, El Quimbo hydroelectric project, Huila, Colombia. Error band is $\pm 1 \mathrm{SE}$. The elevation was significantly different among all zones, while the fragment edge index showed significant differences between zones 1 and 2
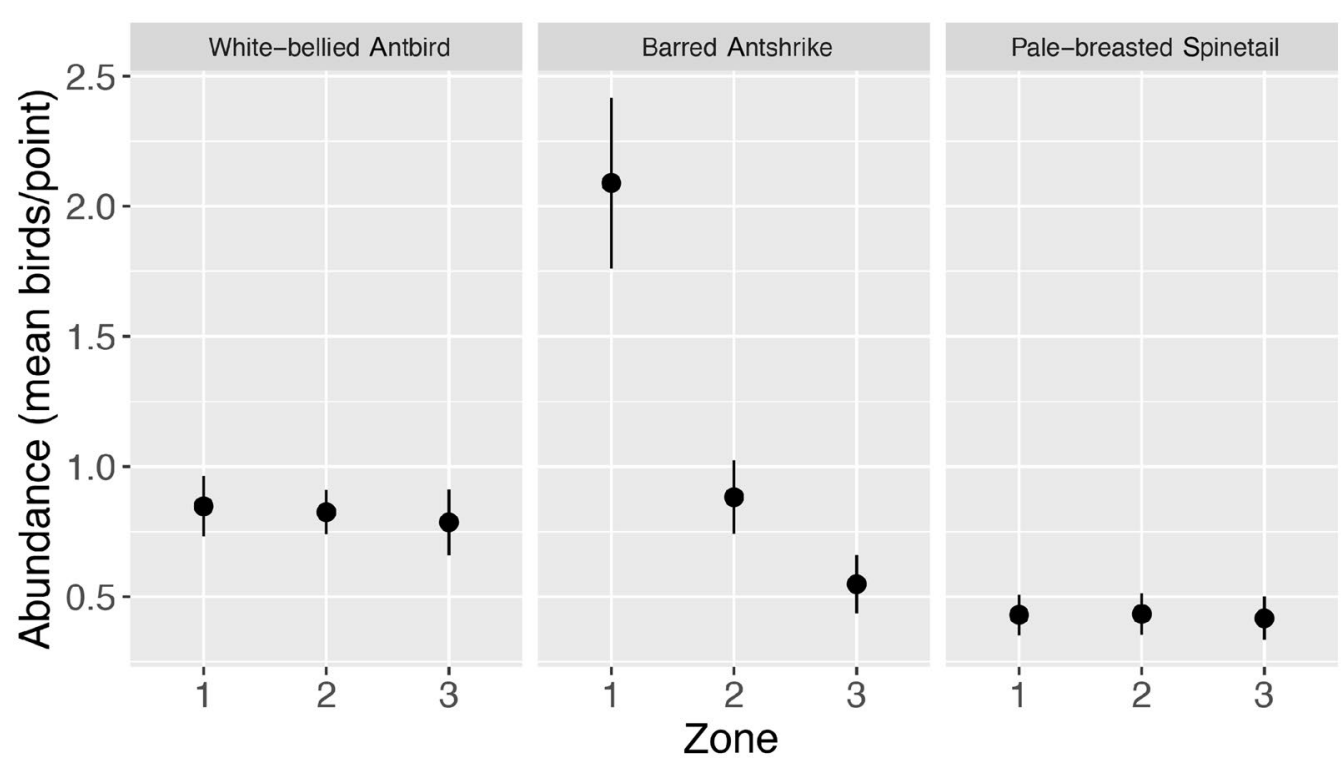

Fig. 5 Predicted relative abundance \pm 1 SE of White-bellied Antbird, Barred Antshrike, and Pale-breasted Spinetail from averaging models based on habitat and landscape variables (see Table 4) in three zones of the study area, El Quimbo hydroelectric project, Huila, Colombia

$(61.2 \% \pm 1.32 \%)$ and thicket fragments $(61.9 \% \pm 1.23 \%)$ (Additional file 2). Hence, climatic conditions are among the environmental factors influencing the preference of White-bellied Antbirds for forest fragments over shrubland and thicket fragments.
The leaf litter had no effect on the White-bellied Antbird abundance, which could be because we measured it just once in a year; thus, we only captured a snapshot of the real conditions, especially because the tropical dry forest has deciduous trees that lose their leaves during the dry season. Consequently, the leaf litter depth variation 
throughout the year is larger than that measured in our study (Marra et al. 2015). Additionally, White-bellied Antbirds were positively associated with the slope, which could be due to the fact that steeper areas were less likely to be transformed into agricultural land or human settlement. Finally, the antbird should be a useful conservation indicator because of its association with larger forest fragments.

Because the Pale-breasted Spinetail abundance was strongly associated with fragments of shrubland, less with thickets and even less with forests-and because the fragment edge index had a strong positive association with their numbers-we agreed with the authors who considered it as an open vegetation species that benefits from fragmentation (Marone 1992; Remsen 2018). Considering that the spinetail is highly associated with shrubland fragments and areas with high amounts of edges, we propose it to be an indicator species for fragmentation in restoration areas.

Given that some authors consider the Barred Antshrike to be a generalist species and others consider it a forest fragment generalist, we expected that it would take advantage of early vegetation successional stages, as well as forests in the disturbance gradient (Sekercioglu 2009; Akresh et al. 2015). Instead, we found a strong association of the species with shrubland and thicket fragments but not with forest fragments, which is in accordance with the results of Gillies and St Clair (2010) and Gaitán García (2013). However, we found evidence that the antshrike abundance was negatively associated with the fragment edge index and thus with fragmentation, agreeing with other authors' findings, which suggest that some disturbance-dependent birds are sensitive to fragmentation, preferring larger and more contiguous habitat patches and developing unique foraging strategies in the tropical understory (Mansor et al. 2018; Roberts and King 2019). We consider the negative relationship between Barred Antshrikes and slope because historically, flatter areas have been converted from forest into settlements and agricultural land, resulting in the current fragments of shrubland and thickets.

The Barred Antshrike abundance was higher in Zone 1 , medium in Zone 2, and lower in Zone 3. Even though this species prefers shrubland fragments over forest and thicket fragments, lower fragmentation at Zone 1 could more greatly benefit the species than could that at Zone 2. Likewise, differences in the area of shrubland fragments could be the key factor benefiting their abundance in Zone 2 over Zone 3 (Table 3).

Generally, the most important variables in the habitat models of these three species agree with those reported by Franklin et al. (2000), who suggested that the amount of habitat (area of fragments) and the level of fragmentation (edge index) are important covariates related to bird populations.

We identified some weaknesses associated with the research that readers should be aware of in our discussion and conclusions. First, habitat measures and bird counts were obtained for just one year; hence, annual variations in habitat variables and bird abundance were not considered. Second, as the habitat variables were not evaluated across the entire year, climate season variation was not recorded. Third because of logistics, the observers at some points were different, affecting the detectability of birds and objectiveness in habitat measures. Finally, including midstory or overstory insectivorous bird species would have been more informative and useful for guiding the restoration effort. However, most vegetal covers of the area have only understory stratum, like many shrubland, thicket, or short forest fragments; thus, we tried to track species that would be present across the entire area. We propose future research of these birds using radiotelemetric techniques to determine their home range to relate them to the population and habitat traits and therefore assist restoration. The habitat-species abundance assessment of the relationship between tropical understory insectivores and disturbance and the focus on the identification of restoration priorities represent the novelty of this research.

\section{Conclusions}

We present evidence that our study area encompasses a gradient of disturbance representing different levels of habitat quality for the three bird species. White-bellied Antbird, Barred Antshrike, and Pale-breasted Spinetail are considered to be in the same trophic group; however, they showed variations in the preference of different stages of succession and responded to distinct characteristics of the landscape. In that sense, these understory insectivorous birds are excellent targets for research in the area for elucidating their habitat relationship and for being indicator species of the disturbance levels. We expect that our findings will improve the management decisions of the study area, especially because this is land left for restoration and protection. A restored dry forest around the "El Quimbo" dam would benefit not only the bird species in this study, but all understory insectivorous birds. As management actions, we suggest increasing the area of fragments and connectivity of forest fragments, decreasing edges, enriching understory with plant species of shrubland, thicket, and forest fragments that increase perches and decrease the amount of cattle. Additionally, as indicated by Castaño-Villa et al. (2014), increasing spatial variation in the forest intra-habitat structural variable features "stem diameter" and "basal area" may increase the insectivorous bird abundance in 
reforested areas. In the end, we propose the White-bellied Antbird as a conservation indicator species and the Pale-breasted Spinetail as a fragmentation indicator species in this area, given their relationships with the habitat and the ease of sampling (Neimi and McDonald 2004).

\section{Supplementary information}

Supplementary information accompanies this paper at https://doi. org/10.1186/s40657-020-00219-4.

Additional file 1. Vegetation key for the definition of vegetal cover type in the field.

Additional file 2. Relationship of temperature with time, elevation, and vegetation cover type. Relationship between relative humidity and both elevation and vegetation cover type.

Additional file 3. $R$ code for data analysis.

Additional file 4. Graphics of GLM support model variables for the three species.

\section{Acknowledgements}

We are grateful to the Universidad National's undergraduate students and members of the research seedbed: Daniela Diaz, Angela Sierra, and the biologist Jenifer Rojas for their help as field assistants. We also thank Hernan Serrano for the development of the thematic map and Fundación Natura and its entire staff for logistical and similar support, within their "Programa De Restauración Ecológica De Bosque Seco Tropical, Central Hidroeléctrica El Quimbo". Finally, we would like to thank Editage (www.editage.com) for English language editing.

\section{Authors' contributions}

$\mathrm{CL}$ was involved in all phases of the work. OM helped with the design proposal, obtaining field-phase data, and writing. DK helped with the statistical analysis and writing. MS helped with the statistical analysis and guidance of $R$ coding. LAP was involved in the field data processing and acquisition. AR suggested habitat variables for analysis and geographical information system procedures. All authors read and approved the final manuscript.

\section{Funding}

We thank the Universidad Nacional of Colombia (proposal Hermes 41471), the Rufford Foundation, and the Colombian Science Ministry (Minciencias) for their financial support through the different phases of this research. Additionally, we thank Fulbright Colombia for their financial support and the University of Massachusetts Amherst for their space and time for the data analysis phase. Finally, we thank the Idea Wild organization for the provision of valuable field equipment.

\section{Availability of data and materials}

The datasets used and/or analyzed during the current study are available from the corresponding author upon reasonable request. The $\mathrm{R}$ code is included in Additional file 3.

\section{Ethics approval and consent to participate}

Not applicable.

\section{Consent for application}

Not applicable.

\section{Competing interests}

The authors declare that they have no competing interests.

\section{Author details}

${ }^{1}$ Instituto de Ciencias Naturales, Universidad Nacional de Colombia, Bogotá, Colombia. ${ }^{2}$ Northern Research Station, USDA Forest Service, University of Massachusetts, 204 Holdsworth Hall, Amherst, MA 01003, USA. ${ }^{3}$ Instituto Internacional en Conservación y Manejo de Vida Silvestre, Universidad Nacional, Apartado, 1350-3000 Heredia, Costa Rica.
Received: 21 February 2020 Accepted: 18 August 2020

Published online: 02 September 2020

\section{References}

Akresh ME, King DI, Brooks RT. Demographic response of a shrubland bird to habitat creation, succession, and disturbance in a dynamic landscape. For Ecol Manage. 2015;336:72-80.

Andriolo A, Piovezan U, Da Costa MJRP, Torres HA, Vogliotti A, Zerbini AN, et al. Severe population decline of marsh deer, Blastocerus dichotomus (Cetartiodactyla: (ervidae), a threatened species, caused by flooding related to a hydroelectric power plant. Zoologia. 2013;30:630-8.

ArcGIS [software GIS]. Version 10.0. Redlands: Environmental Systems Research Institute, Inc.; 2010.

Barrance A, Schreckenberg K, Gordon J. Conservación mediante el uso: Lecciones aprendidas en el bosque seco tropical mesoamericano. In: Barrance A, Schreckenberg K, Gordon J, editors. Londres: Overseas Development Institute; 2009. https://www.odi.org/sites/odi.org.uk/files/odi-assets/publi cations-opinion-files/4428.pdf.

Benedict M, McMahon E. Green infrastructure: smart conservation for the 21st century. Renew Resour J. 2002;20:12-7.

Block WM, Brennan LA. The habitat concept in ornithology: theory and applications. Curr Ornithol. 1993:11:35-91.

Burnham KP, Anderson DR. Model selection and multi-model inference: a practical information-theoretic approach. 2nd ed. New York: Springer; 2002.

Canaday C. Loss of insectivorous birds along a gradient of human impact in Amazonia. Biol Conserv. 1997;77:63-77.

Castaño-Villa GJ, Ramos-Valencia SA, Fontúrbel FE. Fine-scale habitat structure complexity determines insectivorous bird diversity in a tropical forest. Acta Oecol. 2014:61:19-23.

Castaño-Villa GJ, Santisteban-Arenas R, Hoyos-Jaramillo A, Estévez-Varón JV, Fontúrbel FE. Foraging behavioural traits of tropical insectivorous birds lead to dissimilar communities in contrasting forest habitats. Wildlife Biol. 2019;1:1-6.

Chandler RB, King DI. Habitat quality and habitat selection of golden-winged warblers in Costa Rica: an application of hierarchical models for open populations. J Appl Ecol. 2011;48:1038-47.

Cosson JF, Ringuet S, Claessens O, De Massary JC, Dalecky A, Villiers JF, et al. Ecological changes in recent land-bridge islands in French Guiana, with emphasis on vertebrate communities. Biol Conserv. 1999;91:213-22.

DiGiovanni A, Pollock HS. White-bellied Antbird (Myrmeciza longipes). In: Schulenberg TS, editor. Neotropical Birds Online. Ithaca: Cornell Lab of Ornithology; 2018.

Edwards E. A broad-scale structural classification of vegetation for practical purposes. Bothalia. 1983;14:705-12.

Fearnside PM. Análisis de los principales proyectos hidro-energéticos en la región amazónica. 2014. https://doi.org/10.13140/RG.2.1.3609.8083.

Franklin AB, Anderson DR, Gutiérrez RJ, Burnham KP. Climate, habitat quality, and fitness in Northern Spotted Owl populations in Northwestern California. Ecol Monogr. 2000;70:539-90.

Gaitán García CD. Temporada reproductiva y densidad populacional en tres especies de aves de la familia Thamnophilidae del bosque seco tropical en el departamento del Tolima. Universidad del Tolima, 2013.

Gillies CS, St Clair CC. Functional responses in habitat selection by tropical birds moving through fragmented forest. J Anim Ecol. 2010;47:182-90.

Grosjean P, Ibanez F. pastecs: Package for analysis of space-time ecological series. R package version 1.3.21. 2018. https://CRAN.R-project.org/packa ge $=$ pastecs.

Hilty SL, Brown WL. Guía de las aves de Colombia. Cali, Colombia: American Bird Conservancy; 2001.

Kilpatrick AM, Salkeld DJ, Titcomb G, Hahn MB. Conservation of biodiversity as a strategy for improving human health and well-being. Philos Trans R Soc B. 2017:372:1-9.

Kleiber C, Zeileis A. Applied Econometrics with R. New York: Springer-Verlag; 2008. https://CRAN.R-project.org/package=AER.

Koloff J, Mennill D. Barred Antshrike (Thamnophilus doliatus), version 1.0. In: Schulenberg TS, editor. Neotropical Birds Online. Ithaca: Cornell Lab of Ornithology; 2011a. https://doi.org/10.2173/nb.barant1.01.

Koloff J, Mennill D. Aggressive responses to playback of solos and duets in a Neotropical antbird. Anim Behav. 2011;82:587-93. 
Loaiza C. Variación demográfica de aves insectívoras del sotobosque en relación con la calidad del hábitat en un bosque seco tropical. Universidad Nacional de Colombia. 2020.

Losada-Prado S, Molina-Martinez Y. Avifauna del bosque seco tropical en el departamento del Tolima (Colombia): análisis de la comunidad. Caldasia. 2011;33:271-94.

Mansor MS, Ramli R. Foraging niche segregation in Malaysian babblers (Family: Timaliidae). PLoS ONE. 2017;12:1-13.

Mansor MS, Nor SM, Ramli R, Sah SAM. Niche shift in three foraging insectivorous birds in lowland Malaysian forest patches. Behav Processes. 2018;157:73-9.

Marone L. Estatus de residencia y categorización trófica de las especies de aves en la Reserva de la Biosfera de Ñacuñán. Mendoza El Hornero. 1992;13:207-10.

Marra PP, Remsen JV. Insights into the maintenance of high species diversity in the Neotropics: habitat selection and foraging behavior in understory birds of tropical and temperate forests. Ornithol Monogr. 1997;48:445-83.

Marra PP, Studds CE, Wilson S, Sillett TS, Sherry TW, Holmes RT, et al. Nonbreeding season habitat quality mediates the strength of densitydependence for a migratory bird. Proc R Soc B. 2015;282:1-8.

Morales N. Caracterización de fauna en unidades de manejo del plan piloto de restauración ecológica en el área de compensación del proyecto hidroeléctrico El Quimbo. Caracterización de avifauna. 2015.

Natura F. Aproximaciones al ecosistema de referencia para los procesos de restauración ecológica del proyecto hidroeléctrico El Quimbo. 2015.

Natura F. Así avanza el Plan Piloto de Restauración Ecológica del bosque seco tropical en cuatro municipios del Huila/Noticias, Bogotá Colombia. 2017. https://natura.org.co/asi-avanza-el-plan-piloto-de-restauracion-ecolo gica-del-bosque-seco-tropical-en-huila/.

Niemi GJ, McDonald ME. Application of ecological indicators. Annu Rev Ecol Evol. 2004;35:89-111.

Pandit MK, Grumbine RE. Potential effects of ongoing and proposed hydropower development on terrestrial biological diversity in the Indian Himalaya. Conserv Biol. 2012;26:1061-71.

Pinzón CA. Restauración ecológica del bosque seco - proyecto hidroeléctrico El Quimbo - Informe Final. 2014.

Pizano C, Garcia H. El bosque seco tropical en Colombia. In: Pizano C, Garcia H, editors. Bogotá: Instituto de Investigación de Recursos Biológicos Alexander von Humboldt (IAvH); 2014.

Pollock HS, Cheviron ZA, Agin TJ, Brawn JD. Absence of microclimate selectivity in insectivorous birds of the Neotropical forest understory. Biol Conserv. 2015;188:116-25.

Poulin B, Leeebvre GTAN, McNeil R. Diets of land birds from northeastern Venezuela. Condor. 1994;96:354-61.
R Core Team. R: A language and environment for statistical computing. Vienna: R Foundation for Statistical Computing; 2018. https://www.R-project.org/. Remsen JV Jr. Palebreasted Spinetail (Synallaxis albescens). In: del Hoyo J, Elliott A, Sargatal J, Christie DA, de Juana E, editors. Handbook of the Birds of the World Alive. Barcelona: Lynx Edicions; 2018. https://www.hbw.com/ node/56433. Accessed 27 Aug 2018.

Roberts HP, King DI. Variation in plumage reflects avian habitat associations not revealed by abundance. Wilson J Ornithol. 2019;131:339-47.

Rosenberg KV. Dead-leaf foraging specialization in tropical forest birds. PhD Thesis. Lousiana: Lousiana State University and Agricultural and Mechanical College; 1990

Sekercioglu CH. Tropical ecology: riparian corridors connect fragmented forest bird populations. Curr Biol. 2009;19:R210-R213213.

Sigel BJ, Sherry TW, Young BE. Avian community response to lowland tropical rainforest isolation: 40 years of change at La Selva Biological Station. Costa Rica Conserv Biol. 2006;20:111-21.

Stouffer PC, Bierregaard RO. Use of Amazonian forest fragments by understory insectivorous birds: effects of fragment size, surrounding vegetation and time since isolation. Ecol Monogr. 1995;76:2429-45.

Stratford JA, Stouffer PC. Local extinctions of terrestrial insectivorous birds in a fragmented landscape near Manaus. Brazil Conserv Biol. 1999;13:1416-23.

Tamayo AM. Evaluación de riesgos de origen natural y antrópico que pueden afectar el proceso de restauración ecológica del bosque seco tropical en el área de compensación ambiental de la central hidroeléctrica El Quimbo. Bogotá, Colombia: Pontificia Universidad Javeriana, Facultad de Estudios Ambientales y Rurales, Maestría en Gestión Ambiental; 2020.

Toms JD, Schmiegelow FK, Hannon SJ, Villard MA. Are point counts of boreal songbirds reliable proxies for more intensive abundance estimators? Auk. 2006;123:438-54

Vale MM, Cohn-Haft M, Bergen S, Pimm SL. Effects of future infrastructure development on threat status and occurrence of Amazonian birds. Conserv Biol. 2008;22:1006-155.

Walther BA. Vertical stratification and use of vegetation and light habitats by Neotropical forest birds. J Ornithol. 2002;143:64-81.

Wickham H. ggplot2: Elegant graphics for data analysis. New York: SpringerVerlag; 2016.

Wilke CO. cowplot: Streamlined plot theme and plot annotations for 'ggplot2'. R package version 0.9.4. 2019. https://CRAN.R-project.org/packa ge= cowplot.

Zimmer K, Isler ML, Christie DA. Barred Antshrike (Thamnophilus doliatus). In: del Hoyo J, Elliott A, Sargatal J, Christie DA, de Juana E, editors. Handbook of the Birds of the World Alive. Barcelona: Lynx Edicions; 2018. https:// www.hbw.com/node/56662. Accessed 30 Aug 2018.
Ready to submit your research? Choose BMC and benefit from:

- fast, convenient online submission

- thorough peer review by experienced researchers in your field

- rapid publication on acceptance

- support for research data, including large and complex data types

- gold Open Access which fosters wider collaboration and increased citations

- maximum visibility for your research: over $100 \mathrm{M}$ website views per year

At BMC, research is always in progress.

Learn more biomedcentral.com/submissions 